\title{
To Examine Coping Adaptive Strategies Used by Households and Make Policy Recommendations for Addressing Future Climate Change Impacts on Livelihoods in Kapsokwony Division, Mt. Elgon Sub- County, Bungoma County, Kenya
}

Sindani Bon Bonzemo: Institute of Climate Change and Adaptation, University of Nairobi, Chiromo campus, Nairobi, Kenya.

\begin{abstract}
Long and short term changes in climate are disproportionately affecting all parts of the world in equal measure. The most impacted by vagaries of climate change are the most vulnerable and the poor who live in the developing world. Climate change and climate variability impacts the smallholder farmers though they continue to apply traditional technologies in order to cope with climate change vulnerability. In most of the parts the world over, coping strategies are lacking especially in the African States. Trans-disciplinary research approach was used to analyze the perception of community's' responses to climate change and climate variability at the household level. The purpose of this study was to build new transformation knowledge by integrating the traditional and the modern adaptive technologies in order to transform lives of the indigenous communities in the study area. This paper therefore explores and highlights the existing and modern technologies which can be employed by farmers to counteract the impacts of climate change and climate variability. Primary data was collected through in-depth and informant interviews together with Focused Group Discussions (FGDs) and a structured questionnaire administered to 384 household heads in twelve sub-locations in the study area (Kapsokwony Division) formed the basis of these policy recommendations. Secondary data constituting rainfall and temperature parameters was collected from Kenya Meteorological Department (KMD). The long and short term integrated adaptive strategies and policy recommendations generated and developed by all the actors including those from the academia and the traditional communities during the research are meant to build climate resilience and adaptive capacity at local and national levels. A framework that has been developed by this research will help support policy decisions in conservation agriculture and livestock rearing systems, water resource management, change in social behavior, accessing early warning information, promotion of organic farming and human health systems. If fully implemented these policy recommendations will go a long way to bring a paradigm shift that will improve livelihoods and social economic development in the region. These recommendations can be replicated in any other region of the world to bring about desired changes to a people impacted by climate change. The research study achieved capacity building, resilience, adaptive learning, change in attitude and behavior, community empowerment, application of transformation knowledge as well as climate change awareness amongst area residents. The new societal knowledge was used to elucidate long term policies and adaptive strategies to enhance climate resilience, help eliminate poverty levels, improve livelihoods and sustain social economic development. The study recommends collaboration among stakeholders and integration of various sources of knowledge in addressing climate change and climate variability among residents in Kapsokwony Sub-county. Further research should be carried out in the future to corroborate these findings.
\end{abstract}

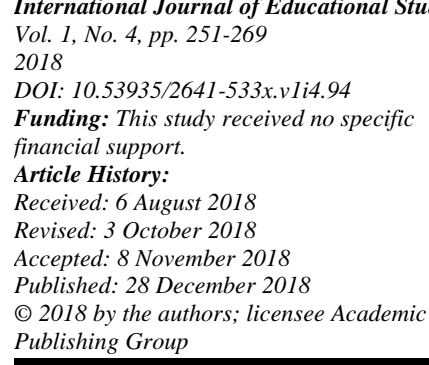




\section{Introduction}

\subsection{Background}

Climate change is one of the most serious threats to sustainable development globally. Increasing frequency and intensity of extreme weather events and progressive slow-onset climate-related threats will worsen the vulnerability of poor households and communities in developing countries, particularly in Least Developed Countries (LDC's), many of which are situated in Sub Saharan Africa. Their capacity to cope with the impacts of extreme weather events and adapt to slow-onset climatic changes is often limited. The impact of climate change despite mitigation and adaptation efforts has come to be known as 'loss and damage' in the past few years. In 2010, during the $16^{\text {th }}$ Conference of the Parties (COP 16) of the United Nations Framework Convention on Climate Change (UNFCCC) in Cancun, it was recognized that joint international efforts were needed to better understand and address such losses and damages.

This research paper looks at loss and damage associated with adverse effects of vagaries of climate change in the study area, Kenya. The Kenyan Case Study investigated impacts of coping adaptive strategies on the livelihoods of rural households in Kapsokwony Division Mt. Elgon sub-county, Kenya. The main objective was to study impacts that rural households incurred despite as a result of climate change and climate variability. The study tracks the indigenous technologies used by households to cope with climate vagaries. Specific objectives were to assess impacts of floods on crop production, livestock keeping and fishing; to examine the coping and adaptation strategies used by households and communities; to study to what extent these measures were successful in avoiding loss and damage; and to make policy recommendations for addressing future loss and damage.

The study area is inhabited by between 90, 000 - 100, 000 people the majority of them being of Saboat origin, the Bukusus and the Iteso. The communities which inhabit the study area are highly aware that climate change is occurring. The area is endowed with good volcanic soils hence have high agricultural productivity as compared to the other divisions. The most common impacts cited include unreliable and unpredictable rainfall as well as warmer temperatures. Almost $80 \%$ of the area residents rely on agriculture and livestock rearing for their livelihoods, however, some are involved in un-skilled labour and salaried work which represent important sources of income. Almost all those who were interviewed and participated in the research feel climate change is affecting their farm output and that climate change is causing difficulty in finding water, affecting their livestock production by reducing availability of pasture and caused an increase in animal diseases. The population of the area depicts a predominantly population with the majority of the people living in the rural area although in recent times some residents have moved into the upcoming urban centers. The poverty index in the division is over $56 \%$. The main causes of poverty include natural resources, landlessness, poor rural infrastructure, insecurity, poor marketing system, illiteracy and high school drop-out rates. Other facts include sociocultural barriers, and the dependency syndrome on donor funding and government resources. The population of the youth constitutes about $45 \%$ of the total population. The challenges of the youth include: high employment levels, low participation in decision making, incidences of drug abuse, poor skill development, high poverty levels, cultural practices that affect the youth like early marriages, poor access to reproductive services and high employment and under-employment levels. Gender imbalance is rampant in the area. Very few women own the land and they cannot access resources crucial for production purposes. Men own the land they are able to access production and credit. Though participation of the women in participation of development is gaining ground, it has not yet reached acceptable grounds. Though women account for $50 \%$ of the population, very few households are headed by women. Overall, there is need to ensure adequate participation of women in the development initiatives.

International Journal of Educational Studies Vol. 1, No. 4, pp. 251-269 2018

DOI: $10.53935 / 2641-533 x . v 144.94$ Funding: This study received no specific financial support. Article History:

Received: 6 August 2018

Received: 6 August 2018

Revised: 3 October 2018

Aublished: 28 December 2018

(C) 2018 by the authors; licensee Academic Publishing Group

$\mid 252$

\section{Objective of the Study}

2.1. Main Objective

To track coping indigenous adaptation technologies used by households and to make new policy recommendations to address climate change on livelihoods of subsistence farmers in Kapsokwony Division, Mt. Elgon region, Kenya.

\subsection{Specific Objectives}


- Identify coping indigenous used by households and emerging technologies and innovations for climate change adaptation in the Case Study;

- Build resilience towards climate change adaptation measures at institutional and individual levels in the study area;

- Assess the impacts of climate change and climate variability on food production in the study area;

- Dialogue with communities in the study area to determine long term and short term effective policies and adaptation strategies to counter impacts of climate change;

- Develop adaptive strategies and build capacity of the farming communities in the study area to adapt to climate change vagaries;

- Assess the impacts of climate variability and climate change on water quantity and quality resource availability and management;

- To enhance household and individual behavioral changes towards climate variability adaptation strategies at both individual and institutional levels;

- Put in place a robust framework to support policy decisions in cropping and livestock production systems in the study area

\section{Literature Review}

\subsection{Introduction}

Climate change may affect food systems in a number of ways ranging from direct effects on crop production (changes in rainfall leading to drought or flooding, or cooler temperatures, or warmer leading to changes in the length of growing season), to changes food prices, changes in markets, and supply chain infrastructure. The comparative importance of climate change for food security differs between regions. A number of opinions have been expounded by researchers in an attempt to clarify underlying factors exacerbating food insecurity in the face of climate change, this are not limited to the following.

Nelson et al. (2008) made use of economic modeling to predict that prices of most cereals will rise significantly due to climatic changes leading to a descend in consumption and hence decreased calorie availability and augmented child malnutrition. Several reports indicate that the nutritional value of food, particularly cereals, possibly will also be affected by climate change (Nagarajan et al., 2010). Climate change will also affect the ability of individuals to use food effectively by altering the conditions for food safety and changing the disease pressure from vector, water, and food borne diseases (Schmidhuber \& Tubiello, 2007).

The climatic fluctuations are known to affect post harvest losses and food safety during storage, for example by causing changes in populations of aflatoxin-producing fungi (Cotty \& Jamie-Garcia, 2007)S. It is anticipated that more frequent extreme weather events under climate change will damage infrastructure, with detrimental impacts on food storage and distribution, to which the poor will be most vulnerable (Costello et al., 2009).

\subsection{Climate Change Will Degrade Water Qualities and Quantities}

Residents in the study area heavily depend on stream water for drinking and cooking. Water qualities and quantities are likely to be amplified by climate change in the region. During rains, the proportion of precipitation that runs off is determined by a variety of factors including temperature, wind speed, humidity, solar intensity at the ground, vegetation and soil moisture. Surface water quality and groundwater quantity will be affected by a changing climate. The negative effects of water pollution, including sediments, nitrogen from agriculture, disease pathogens, pesticides, herbicides, salt, and thermal pollution, will be amplified by observed and projected increases in precipitation intensity. Heavy downpours lead to increased sediment in runoff and outbreaks of waterborne diseases. However, pollution has the potential of being diluted in regions that experience increased stream-flow. Waterquality changes during the last decades were probably due to other causes other than climate change. Climate change will place additional burdens on already stressed water systems. Water demands are expected to change with increased temperatures and evaporation is projected to increase over most of the region as temperatures rise. Water pollution exacerbated by anthropogenic activities can contaminate the freshwater supply, affecting public health. Drought related to reduced precipitation, increased evaporation, and increased water loss from plants will affect livelihoods (Sindani, 2013). 


\subsection{Climate Change Threat to Human Health}

Risks to human health in the study region will increase due to climate change. Harmful health impacts of climate change are related to increasing heat stress, waterborne diseases, poor air quality, extreme weather events, and diseases transmitted by insects and rodents. Climate change is known to fuel a rise in the infection of most waterborne diseases because increase in temperatures and humid conditions support the thriving of pathogens which cause these emerging diseases. Children, the elderly, and the poor, are most vulnerable to a range of climate-related health effects. Realistically assessing the potential health effects of climate change must include consideration of the capacity to manage new and changing climate conditions. Whether or not increased health risks due to climate change are realized will depend largely on societal responses and underlying vulnerability. Climate change variability influences the prevalence of communicable diseases such as malaria, cholera and tuberculosis. High incidences of malaria are caused by the spread of vectors into the Mt. Elgon region which is warmer than ever before due to climate change. Emerging evidence indicate that drastic weather patterns now pose a big threat to health, with the emergence of exotic infections. Other diseases linked to climate change in the region include fever, bubonic plague, highland malaria and tuberculosis.

\subsection{Climate Change and Poverty}

The key challenge to food security in Africa Tharaka community not being an exception, is its underdeveloped agricultural sector that is characterized by over reliance on low fertility soils, primary agriculture, minimal use of external farm inputs, significant food crop loss both pre and post harvest, environmental degradation, minimal value addition and product differentiation, and inadequate food storage that result in significant commodity price fluctuation. In Sub-Saharan Africa ninety five percent of the food is grown under rain fed agriculture (Inter Academy Council, 2004). To meet higher demand, food production is obviously of main importance. But poor households' inability to secure food through markets and non-market channels may limit food security even where food is globally abundant (Barrett, 2010). Climate change has the prospective to transform food production, in particular the patterns and productivity of crop, livestock and fishery systems, and to reconfigure food distribution, markets and access (Nelson et al., 2008).

\subsection{Climate Change and Adaptation}

Adaptation is a combination of disaster risk reduction, climate change, environmental management and poverty reduction. Successful adaptation can be accomplished through actions that target and reduce vulnerabilities of poor communities. Communities can develop a common platform to tackle the issue of vulnerability reduction through activities such as disaster risk reduction, climate change environmental management and poverty reduction. Adaptive capacity is key to improving socio-economic characteristics of communities and households as it includes adjustments in both behaviour and in resources and technologies. It is imperative that correct and beneficial technologies are selected for adaptation under prevailing climate conditions and those that might be most adaptive under a future climate. The appropriate are those that build resilience to shocks and support adaptation, and those that represent incremental advances not transformational change (Biagini, Laura, Gallager, \& Ortiz, 2014). Without sufficient scientific knowledge of future conditions technologies can be ineffective, or even harmful, if they are not appropriate under a future climate (Biagini et al., 2014). The researchers are advised to use both top- down and bottom-up approaches adaptation processes because they lead to higher effectiveness, efficiency, equity, flexibility, legitimacy sustainability and replicability (Sherman \& Ford, 2014).

International Journal of Educational Studies Vol. 1, No. 4, pp. 251-269 2018

DOI: 10.53935/2641-533x.v1i4.94 Funding: This study received no specific financial support. financial support.

Article History:
Received: 6 August 2018

Received: 6 August 2018

Revised: 3 October 2018

Accepted: 8 November 2018

(C) 2018 by the authors; licensee Academic

Publishing Group

$\mid 254$

\section{Methodology}

In this section of the research paper of the Case Study, we highlight the study area together with data collection methods which are also detailed. The data collection methods include desk review, in-formant and in-depth interviews, focus group discussions and household questionnaire administration with randomly selected households as respondents of the communities in the study area. This Case Study is the first to be carried out in the area. 


\subsection{Study Area}

Mt. Elgon Ecosystem is one of the very largest water towers in this country. The study area is found approximately on the Kenyan side between longitudes $0^{0} 47^{\prime} 30 \mathrm{~N}-0^{0} 52^{\prime} 30 \mathrm{~N}$ and latitudes $34^{0} 37^{\prime} 30 \mathrm{E}-$ $34^{\circ} 43^{\prime} 0 \mathrm{E}$. Extreme rainfall regimes and temperatures are part of the natural forcings that cause adverse impacts in the upper ecosystem thereby affecting livelihoods in the region. The research area is situated next to the natural forest ecosystem.

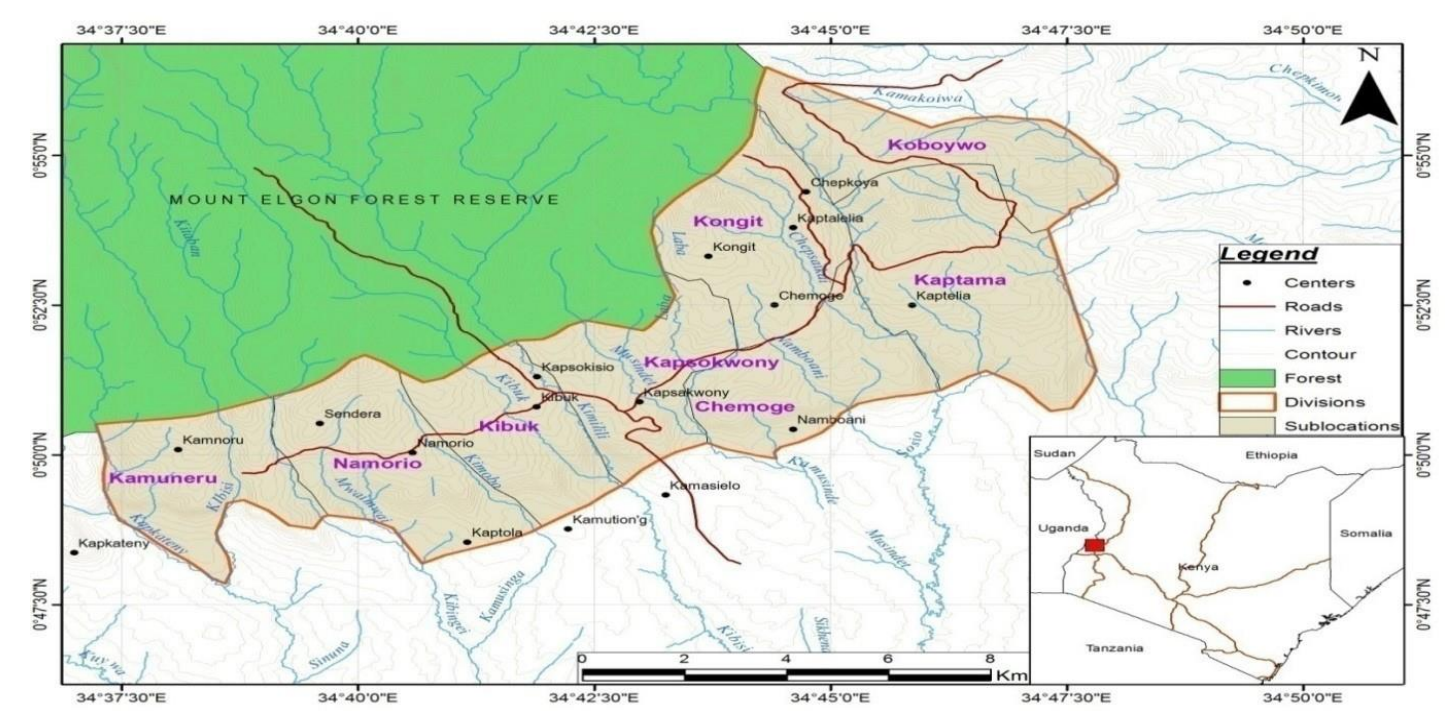

Figure-1. Topography map of Mt. Elgon region, Kenya showing the study area Coordinates: longitudes $0^{0}$ $47^{\prime} 30 \mathrm{~N}-0^{0} 52^{\prime} 30 \mathrm{~N}$ and latitudes $34^{0} 37^{\prime} 30 \mathrm{E}-34^{0} 43^{\prime} 0 \mathrm{E}$.

\section{KAPSOKWONY DIVISION SUB LOCATIONS MAP}

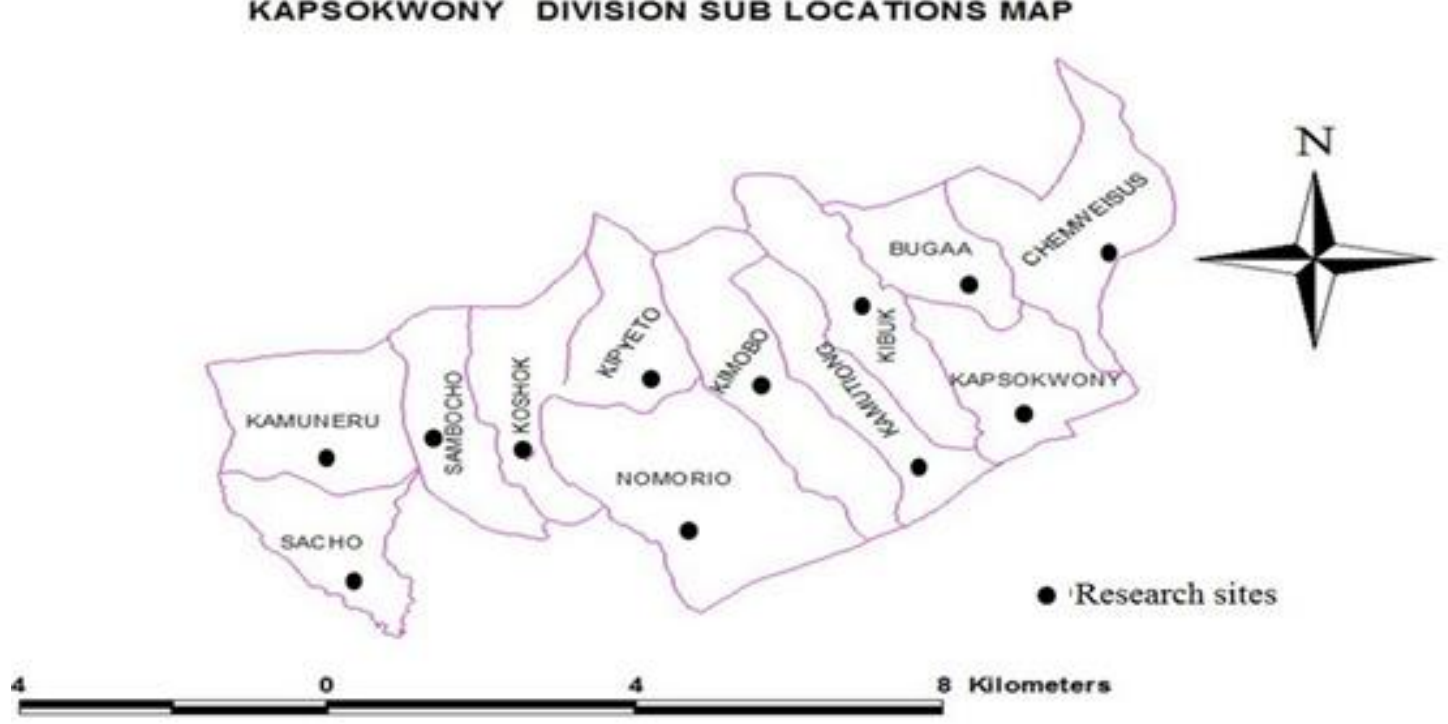

Source:FEW S NETIUSG SINDMA

Figure-2. Map of study area showing sub-locations and research sites Coordinates: longitudes $0^{0} 47^{\prime} 30 \mathrm{~N}-0^{0} 52^{\prime} 30 \mathrm{~N}$ and latitudes $34^{0} 37^{\prime} 30 \mathrm{E}-34^{0} 43^{\prime} 0 \mathrm{E}$.

The erratic weather changes due to climate change impacts in the region have greatly affected livelihoods of the people in the recent past. There is a big relationship between the mountain ecological zones and the people who reside near the forested part of the ecosystem. Thus, the degradation of the existing water supplies is directly linked to the degradation of the forest resources and this is due to impacts of climate change (WWAP, 2009).

Parts of the main physical features in the region are the protruding volcanic rocks which were formed millions of years ago by the process of volcanicity. The landforms and structures of Mt. Elgon 
landmass are changing due to landform evolution and the process of weathering. Landform and weathering processes are controlled by forces that include earth movements or plate tectonics and climate change. Continual fault movements and longtime effects of erosion have been responsible for the shaping of the landscape as seen today (Wesche, 1983). Mt Elgon landscape is also subject to climate change and different types of weathering. The annual alternating wet and dry climatic conditions are the main conditions that are responsible for shaping of the landscape. Water in rivers transport sediments, silt, sand and clay particles which are later deposited in the lowland areas. Most of the erosion takes place upstream and deposition takes place downstream on the floodplain (Wesche, 1983).

\subsection{Data Collection Methods}

Data was collected through an approach that combine a household questionnaire survey, three focus group discussions with a total of 80 women, men and youth, six key informant interviews with representatives of public and private organizations, and four in-depth interviews with some respondents who will participate in the household survey. Administration of the structured questionnaire involved a total of 384 heads of households 32 from each of the sub-locations.

\subsubsection{Desk Review}

Desk review started by highlighting historical trends of climate change challenges as highlighted in the national climate policies through a review of different policies that addressed climate change issues in different national policies whether directly or indirectly. This took into consideration how smallholder farmers' traditional technologies and indigenous adaptation strategies to climate change impacts within the study area could be implemented. Desk review also mirrored the effective adaptation technologies which were used by farmers in the past to combat the vagaries of climate variability.

\subsubsection{Quantitative Data}

The household questionnaire survey generated mostly quantitative data although it also contained open questions that provided qualitative information. The questionnaire had four sections. The first section dealt with general, socio-economic and demographic characteristics. This was followed by two sections on coping with extreme weather events and adaptation to gradual climatic changes to assess the impact of climate stressors on the households, and their strategies to cope with and adapt to the impacts of extreme weather-related events. The last section of the questionnaire uses open questions to examine local perceptions of vulnerability and the ideas of respondents about policy options to reduce climate risks. The questionnaire interviews took approximately 25 to 30 minutes each to complete.

\subsubsection{Qualitative Research Tools}

Qualitative information was obtained through focus group discussions, key informant interviews and in-depth interviews. This information was used to complement the household survey (questionnaire). A Focus Group Discussion (FGD) is a form of interview that involves addressing questions to a group of individuals who have been selected for this specific purpose. In this study, three FGDs were conducted to obtain the experiences of men, women and youth with impact, coping and adaptation to climate extreme impacts. In total there were about 80 participants. The participants were ordinary members of the community and other stakeholders. Interaction among them stimulated ideas and perceptions about climate risks, including perception of change in the frequency and severity of climate impacts over time, drivers of deforestation, impacts, responses, constraints (factors impeding effective coping and adaptation) and policy.

Key informant interviews were used to collect information from people with specific knowledge and International Journal of Educational Studies Vol. 1, No. 4, pp. 251-269 focus group discussions and the questionnaire. The integration of both non-scientific (experiential) and scientific knowledge was of great importance because it had a prominent role in decision making. Observations were made overtime of projected weather patterns/climate change on livelihoods and alterations be recorded and analyzed. Secondary data from meteorological experts of the weather parameters in the region can be of importance in the prediction of climate change scenario. 


\section{Results}

\subsection{Food Security}

A range of strategies have been developed by communities living in the study area to counter the impacts of climate change. In table 2.1 below, the months that showed a large number of responses regarding perception of drought were May, June and July that had 228(59.38\%), 260(67.71\%) and $154(40.10 \%)$ households making a total of $642(167.19 \%)$ whereas the months with least perceptions on food shortage in the past year were January, February, March, September, October, November, December making a total of $3(0.78 \%), 9(2.34 \%), 20(5.21 \%), 13(3.39 \%), 2(0.52 \%), 1(0.26 \%)$ and $2(0.52 \%)$ respectively constituting $50(13.02 \%)$ of the households. The poor are the most vulnerable and they face food shortages especially in the months of May, June and July.

\begin{tabular}{|c|c|c|}
\hline Months & $\begin{array}{ll}\text { Frequen } \\
\text { cy }\end{array}$ & Percentage \\
\hline January & 3 & $0.78 \%$ \\
\hline February & 9 & $2.34 \%$ \\
\hline March & 20 & $5.21 \%$ \\
\hline April & 64 & $16.67 \%$ \\
\hline May & 228 & $59.38 \%$ \\
\hline June & 260 & $67.71 \%$ \\
\hline July & 154 & $40.10 \%$ \\
\hline August & 51 & $13.28 \%$ \\
\hline September & 13 & $3.39 \%$ \\
\hline October & 2 & $0.52 \%$ \\
\hline November & 1 & $0.26 \%$ \\
\hline December & 2 & $0.52 \%$ \\
\hline Total & 807 & 210.16 \\
\hline
\end{tabular}

\subsection{Amount of Food Bought}

In the figure 2.2 below, household respondents gave opinion on how Amount of Food Bought was experienced in the past year indicating that Approximately Half Less, Less Than Half, and More Than Half had the largest number of responses of 153(39.84\%), 90(23.44\%) and 87(22.66\%) respectively making a total of $330(85.94 \%)$. The proportion of missing responses was relatively small $10(2.6 \%)$ so it did not affect the interpretation of the findings. The households that bought every food item consumed were significantly low $15(3.91 \%)$. Such households might very vulnerable with hardly any land to till to produce food for consumption. Those households indicated Missing 10(2.60\%) and Nothing 19(4.95\%) might be deeply entrenched in poverty so they have no money to buy food or have no land to produce food.

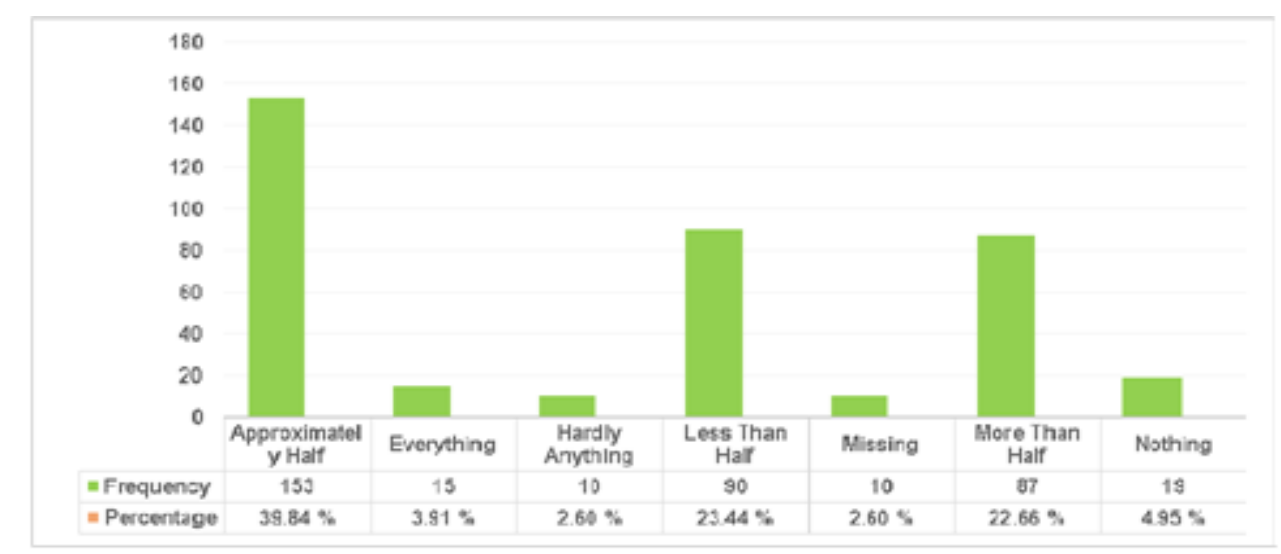

Figure-5.1. Amount of food bought 


\subsection{Modification of Food Consumption}

Climate change and climate variability has an impact on the nature of food that is consumed by most of the households in the study area. Some households may in table 5.15 above some form of modification of food consumption was done by a huge number of households making a total of $366(95.31 \%)$ out of which the households who resorted to having less meals per day was the highest $150(39.06 \%)$. Other measures like adult eat less cheaper meals per day, less people at home, and limit portion sizes $61(15.89 \%), 50(13.02 \%) 40(10.42 \%)$ and $65(16.93 \%)$ respectively making a cumulative total of $216(56.25 \%)$. This depicts the fact that households can access less amounts of food than expected either due to high poverty levels or land fragmentation resulting small portions and rising population.

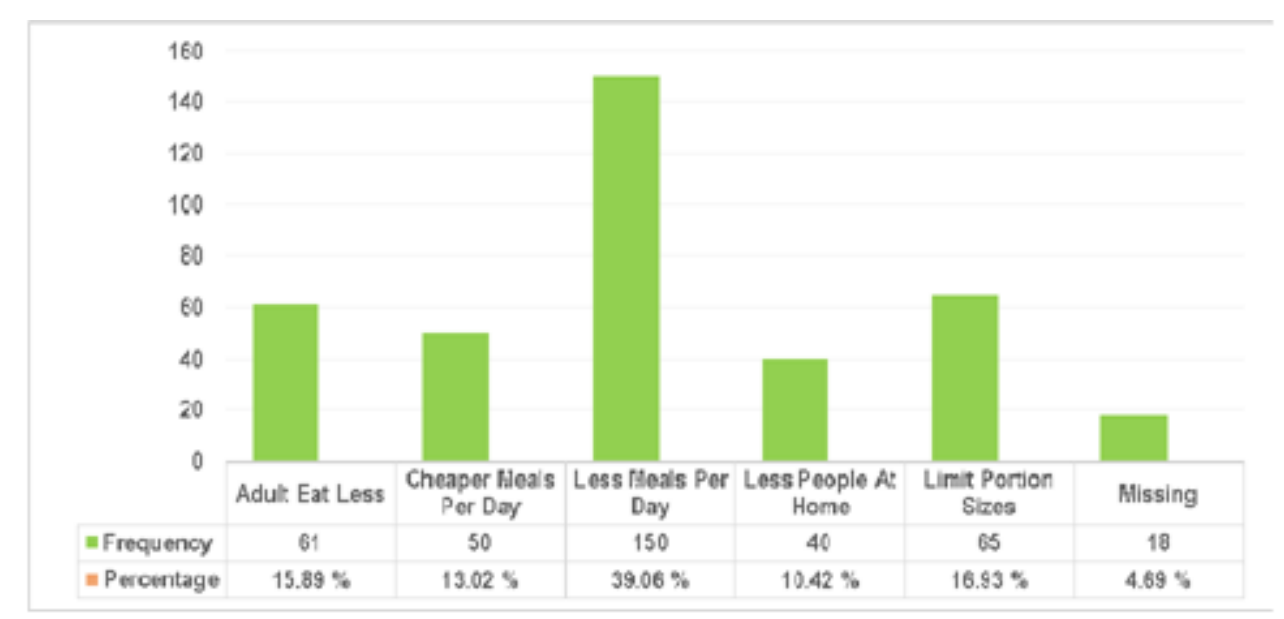

Figure-5.2. Modification of food consumption

\subsection{Perceptions of change in (20 Years)}

Perceptions of change in threats for the past 20 years as shown in table 5.12 below indicated that About The Same and No Less Than Before making 91(23.7\%) and 103(26.82\%) and cumulative total of 194(50.52\%) respectively followed closely by Yes a lot and Yes but only a little constituting $79(20.57 \%)$ and $62(16.15 \%)$ respectively with cumulative total of $141(36.72 \%)$. The proportion of missing responses was relatively small $14(3.65 \%)$ so it did not affect the interpretation of the findings.

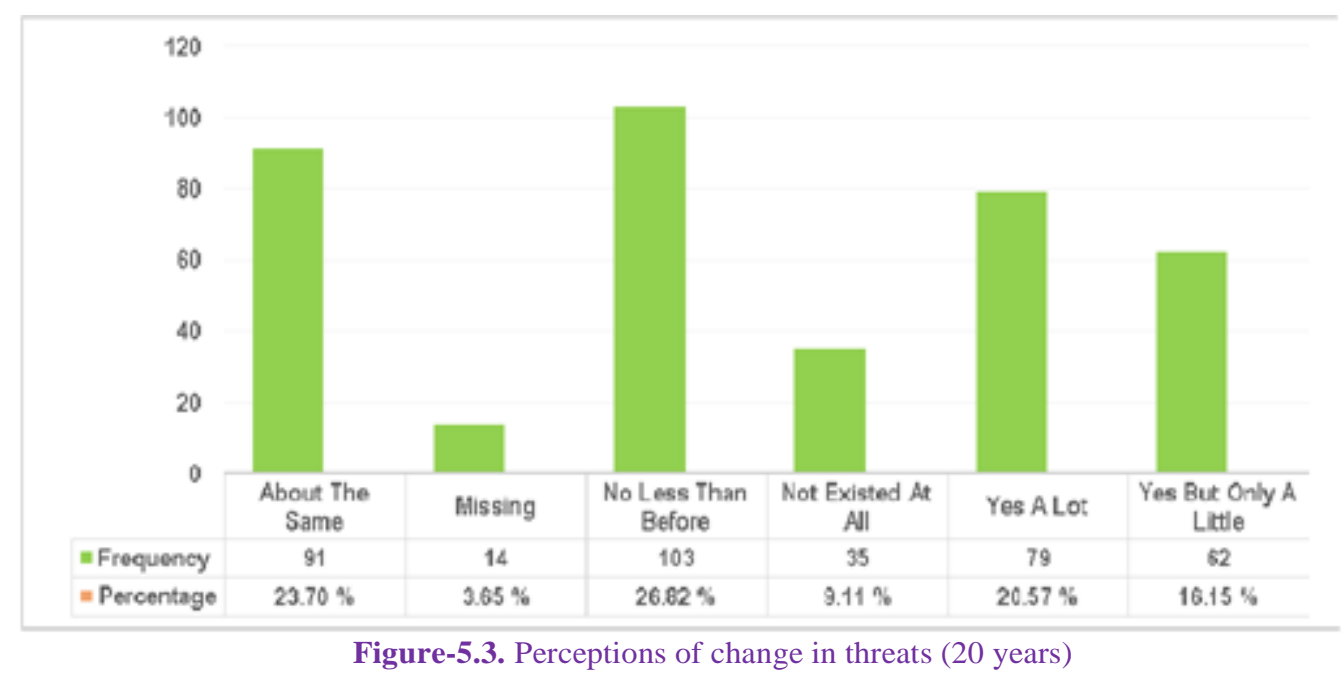

\subsection{Livelihood Diversification}

Figure 2.4 below show that livelihood diversification was not done by most of the households that participated in the survey. A huge majority of the respondents $254(66.15 \%)$ did not diversify whereas the remaining $130(33.85 \%)$ participate out of which majority agreed that they diversified by engaging in 
new non-farm activities 126(32.81\%). To be able to diversify, capital resource is required and yet most are poor households which are very vulnerable to climate vagaries. A reasonable number $126(32.81 \%)$ diversified by engaging in New Non-Farm Activities. This might have been for the fact that they owned some land and input to invest.

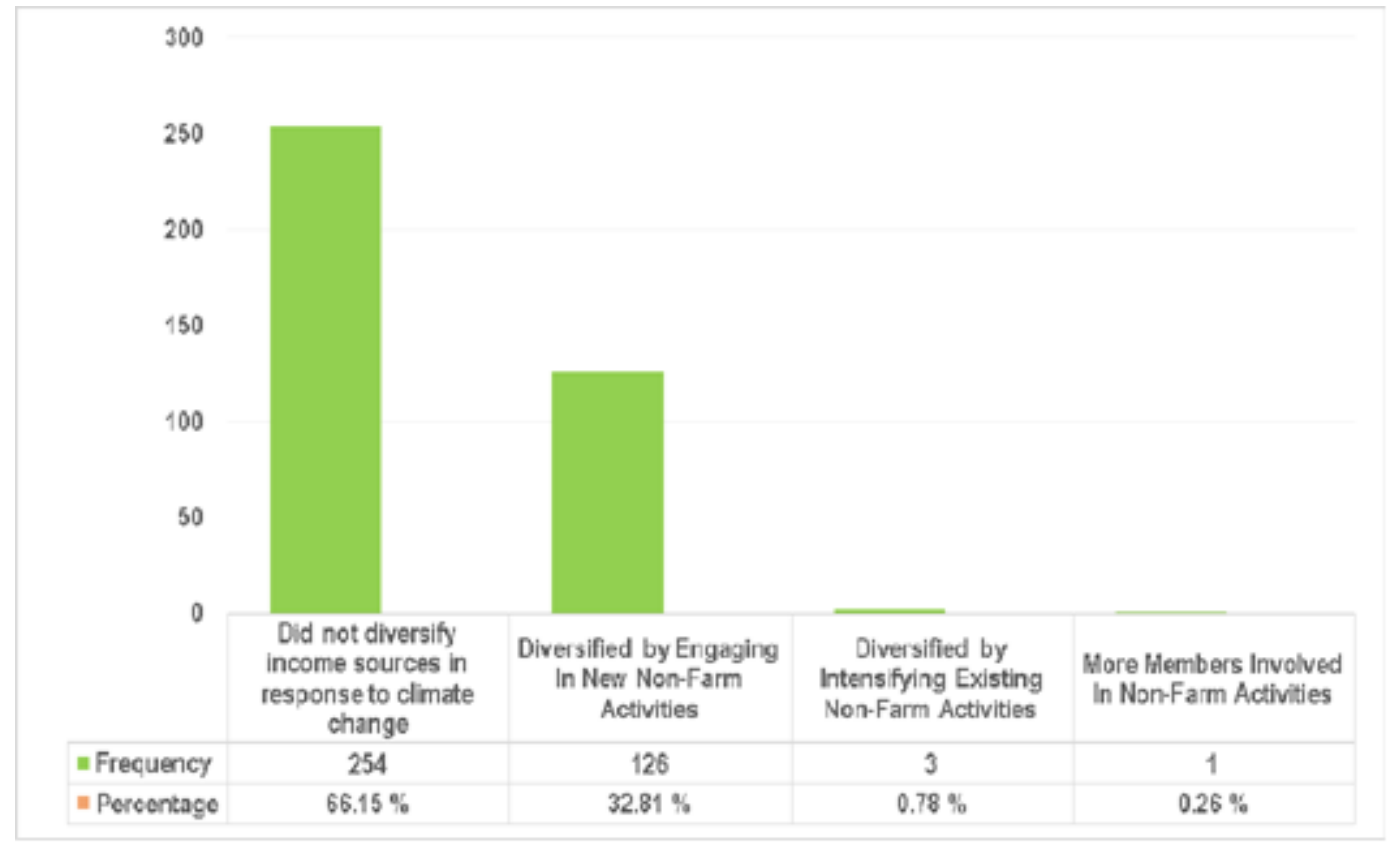

Figure-5.4. Livelihood diversification

\subsection{Coping strategies adapted by households}

As summarized in table 2.2 below, coping strategies adopted by households had a small number of missing cases $8(2.08 \%)$ which did not influence interpretations much. The first three responses with were agreeable most households were Earn Extra Income, Help From Organizations and Help From People making $75(19.53 \%), 95(24.74 \%)$ and $83(21.61 \%)$ respondents respectively and accumulating to $253(65.89 \%)$.the other areas that had an appreciable number of responses were Sale Of Property and Spend Less On Food 40(10.42\%) and 45(11.72\%) making a total of 85(22.14\%).

Table-5.2. Coping strategies adopted by households

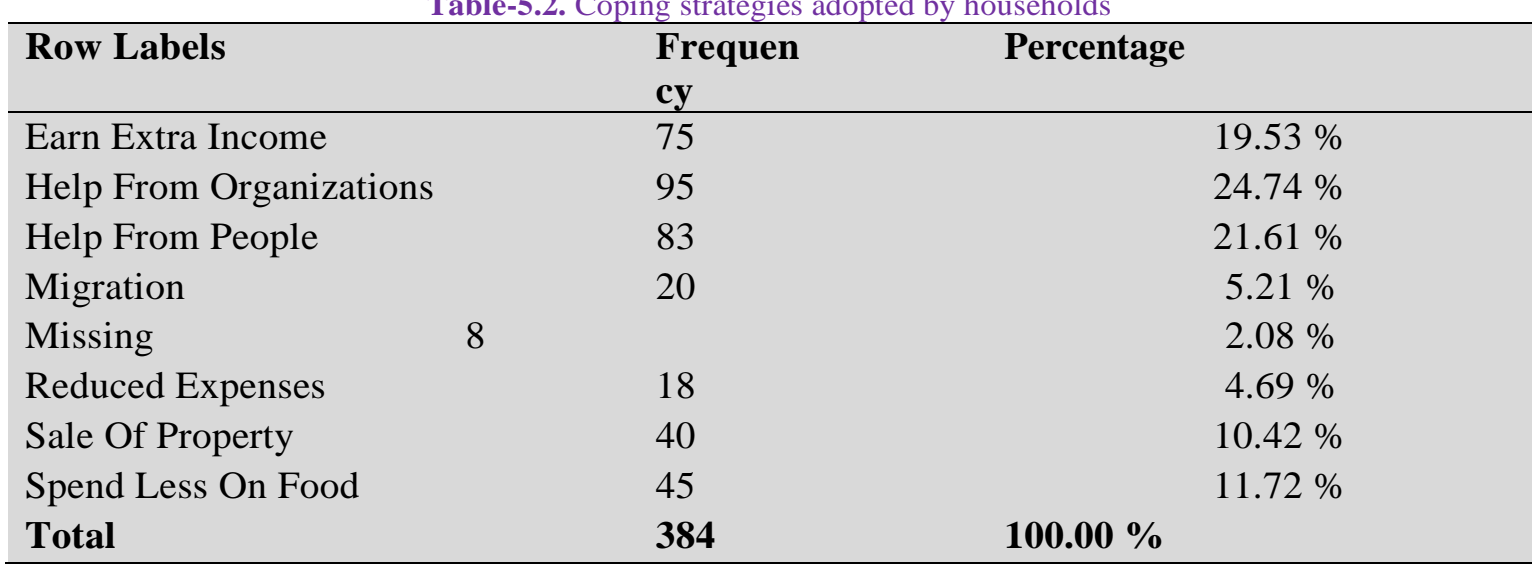


Table-5.3. Coping strategies

This makes them more vulnerable in the face of future climate threats and other misfortunes that can fall on them. The erosive or potentially erosive character of the most commonly adopted coping strategies is summarized in Table 16.

Table-5.5. Non-farm income activities

\begin{tabular}{lcc}
\hline Non-farm income activities & $\begin{array}{l}\text { Frequen } \\
\text { cy }\end{array}$ & Percentage \\
\hline Blue Collar Work*** & 118 & $30.73 \%$ \\
Missing & 5 & $1.30 \%$ \\
Other Non-Farm Self Employment* & 55 & $14.32 \%$ \\
Petty Trade & 106 & $27.60 \%$ \\
White Collar Work** & 100 & $26.04 \%$ \\
Total & $\mathbf{3 8 4}$ & $\mathbf{1 0 0 . 0}$ \\
\hline
\end{tabular}

International Journal of Educational Studies Vol. 1, No. 4, pp. 251-269

2018

I. 10.53935/264l-533xv1i4.94

Funding: This study received no specific

financial support.

Article History:

Revised: 3 October 2018

Accepted: 8 November 2018

Published: 28 December 2018

C) 2018 by the authors: licensee Academic Publishing Group

\begin{tabular}{|c|c|}
\hline Coping strategy & Costs/adverse effects \\
\hline $\begin{array}{l}\text { a)Extra } \\
\text { income generating } \\
\text { activity: }\end{array}$ & $\begin{array}{l}\text { Less time available for primary occupation (usually farming); Hand- } \\
\text { to-mouth existence, hence less chance of capital accumulation; } \\
\text { Sometimes children are withdrawn from school to engage in non- } \\
\text { farm activities and look after livestock to deal with livelihood } \\
\text { impacts; }\end{array}$ \\
\hline b) Sale of property: & $\begin{array}{l}\text { Reduced household asset base: Sale of land for instance lowers food } \\
\text { securit } \\
\text { y and less income from crop sales; Sale of livestock reduces } \\
\text { possibility of animal traction power for farming, income and food } \\
\text { e.g. meat, milk or eggs); }\end{array}$ \\
\hline $\begin{array}{l}\text { c) Modified } \\
\text { food } \\
\text { consumption: }\end{array}$ & $\begin{array}{l}\text { Less food intake or inferior foods means less energy for farming and } \\
\text { other productive activities; Poor nutrition can have serious health } \\
\text { implications, e.g. it can affect brain development especially in very } \\
\text { young children. Among children of school going age, it can affect } \\
\text { educational attainment and hurt livelihoods; }\end{array}$ \\
\hline $\begin{array}{l}\text { d) Exploitation of } \\
\text { forest natural } \\
\text { resources: }\end{array}$ & $\begin{array}{l}\text { During lean periods the households drive livestock to the forest for } \\
\text { grazing and watering; Some go hunting and collect honey from } \\
\text { different points in the forest; They carry out illegal logging, burn } \\
\text { charcoal and in engage fuel-wood collection which they sell to earn } \\
\text { some income; The dependency syndrome rears its head once more; } \\
\text { They plant crops that ripen faster and surplus are sold to earn an } \\
\text { income. }\end{array}$ \\
\hline $\begin{array}{l}\text { e) } \\
\text { Reduced } \\
\text { expenditure } \\
\text { on household } \\
\text { requirements: }\end{array}$ & $\begin{array}{l}\text { Reduced spending on education and withdrawing children from } \\
\text { school affects their future job opportunities; Less money for } \\
\text { healthcare, leading to poor health and reduced productivity; Less } \\
\text { money for house maintenance: poor shelter, hence unsanitary } \\
\text { conditions; }\end{array}$ \\
\hline
\end{tabular}




\subsection{Non-Farm Activities}

Apart from crop cultivation and livestock keeping many people engage in non-farm activities. From the study it was clear that the three main Non-farm income activities for farmers in this area were Blue Collar Work***, Petty Trade and White Collar Work** constituting 118(30.73\%), 106(27.6\%) and $100(26.04 \%)$ respectively making a cumulative total of $324(84.38 \%)$ households. The number of missing responses could not significantly affect the interpretations since they are less than $5 \%$ i.e. $5(1.3 \%)$ respondents. The information is also in figure 9 above.

\subsection{Respondents Perceptions on Sustainability of Livelihoods.}

"I am a poor widow who lacks money to buy land elsewhere. The lady migrated out of Chepyuk Settlement Scheme after her husband was murdered in cold blood by arsonists during the famous land skirmishes of 2007. She now lives in Kapsokwony Township with her children who include four boys and three girls. The migration is attributed to the fact that land in the region has become scarce due to exponential population increase. As at now she stares poverty in her eyes and she has nobody to look up to. Her family members can manage only one meal a day since she moves from house to house looking for house chores on a daily basis which to earn her livelihood and that of her children. She never dreams of a better life in the future and she has left everything else to her Gods."

In-depth interview with Mrs. Judith Bera a widow who lives with her children in Kapsokwony Township on $7^{\text {th }}$ February, 2016.

Similarly, the medical doctor in charge of the District Hospital observed that:

"I believe climate change is real and its extreme events are responsible for threats to livelihoods among households. Area residents lack clean drinking water and proper sanitation especially during rainy periods. During enhanced climate events, waterborne diseases become rampant because of increased water pollution. In the uplands, poor farming methods prevail, and haphazard removal of the natural vegetation has opened up the rivers to pollution. Chemical fertilizers carried downstream from open fields end up in river water thereby cause water pollution. Pollution of these river streams has resulted in the river waters which are breeding grounds for microbes or pathogens that cause diseases that have actually kill many people in the region. Amoebic dysentery caused by Entomoeba histolytica protozoan is another waterborne disease that attacks the residents of this area. Other waterborne diseases include giardiasis, typhoid fever, cholera and intestinal fever and malaria.."

Interview with Godfrey Ndara was summarized as follows:

Informant interview with Dr. Edward Simiyu, District Medical Officer, Mt. Elgon District Hospital on 5th January, 2016.

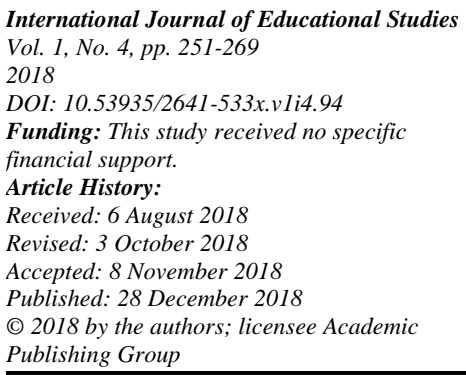


"Climate change is being experienced in the region as indicated by a rise in temperatures and rainfall patterns which have become more erratic, unreliable and unpredictable. Crops now mature faster than ever before. Forest cover is reducing due to human encroachment and environmental degradation. The Plantation Establishment and Livelihood Improvement Scheme (PELIS) which was started in the study area in order improve livelihoods and conserve natural resources have completely been watered down. Farmers do not carry out their roles as stipulated in the agreement with KEFRI because they have not been sensitized about the PELIS process. There are no tree nurseries to replenish the plantations. However, area residents continue to enjoy ecosystem services with impunity. The area experiences low food production and people are poor because of low incomes. Most of the maize (70\%) is grown in the forest and only (30\%) is grown in the villages. They do not plant certified seeds to give expected yields at harvest time. Very few people plant economic trees because of poor financial base." 6

In-depth interview with Godfrey Ndara, 15 ${ }^{\text {th }}$ February, 2016 (resident of Nomorio sub-location) We carried out an in-depth interview with a youth from Kibuk sub-location and he said that:

"The main problem with the effects of climate change threats to livelihoods in
Kapsokwony Division is lack of money, adaptive knowledge and skills. Therefore, some
people especially the youth have abandoned their homes and migrated to mushrooming
urban centers in the region. Some are embroiled in boda boda business, while some are
engaged in video and cyber business so they can put something on the table at the end of
the day. Some have gone into self employment especially in the horticultural farming
where they are trying a hand to raise market oriented products that include green kales,
potatoes, tomatoes, onions and carrots. To alleviate poverty the youth are conceiving
innovative ideas of engaging in fish farming through formation of youth committees in
order to attract funding from the World Bank through Department of Special Programmes
(DSPs). The youth have joined Community Driven Development Committees (CDDCs)
where they are trained for example to make budgets, keep records, make informed
decisions and on achieving set targets."

In-depth interview with Maurice Kinyanja, Kibuk sub-location, 27 ${ }^{\text {th }}$ January, 2016.

An interview with Kiterie Kipsesei at his home near Kapsokwony town. He stated that:

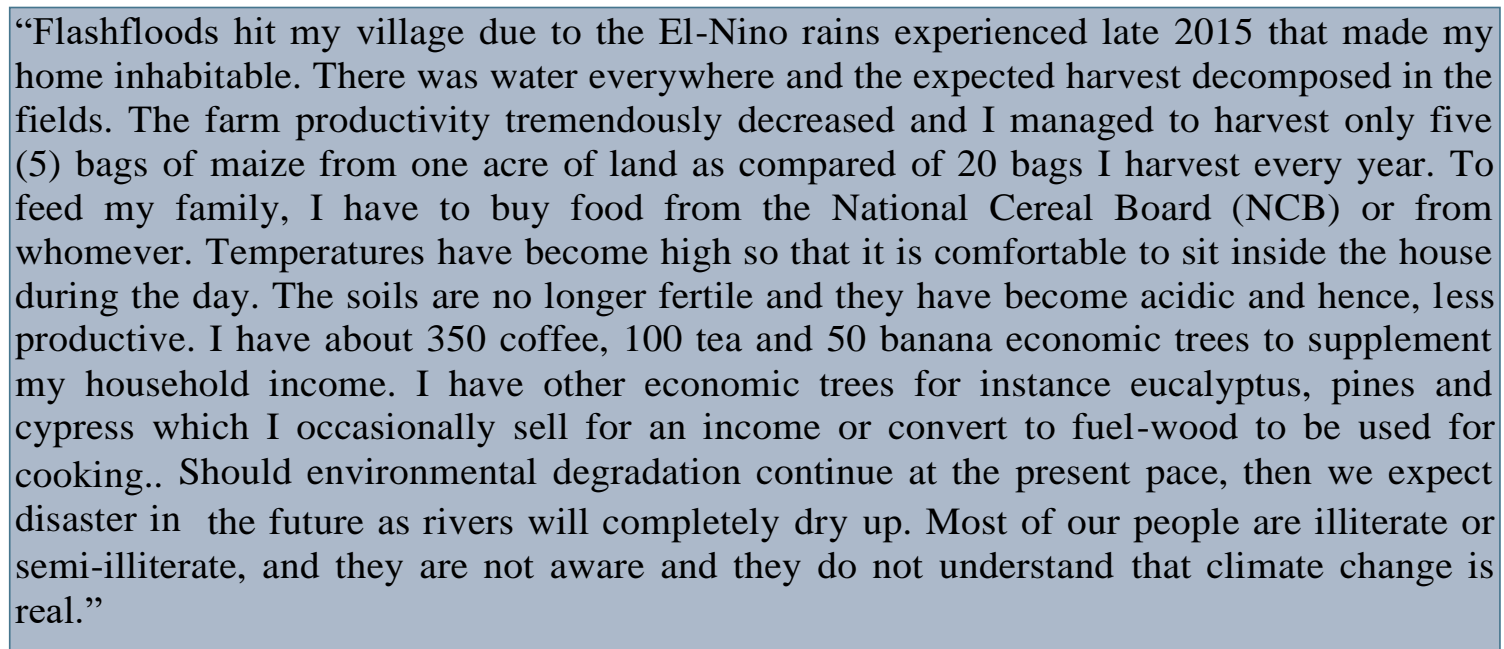

International Journal of Educational Studies Vol. 1, No. 4, pp. 251-269

2018

DOI: 10.53935/2641-533x.v1i4.94 Funding: This study received no specific

Article History:

Received: 6 August 2018

Revised: 3 October 2018

Accepted: 8 November 2018

Published: 28 December 2018

(C) 2018 by the authors; licensee Academic Publishing Group

| 262 
In-depth interview with Kiterie Kipsisei on $23^{\text {rd }}$ January, 2016 (Bugaa sub- location).

"Human activities and altered climatic patterns are the causes to deterioration of important productive sectors like tourism, agriculture and energy sectors in this region. Illegal logging, charcoal burning, over-grazing of animals and human encroachment in the past two decades has resulted in forest degradation and decimation. Planting of eucalyptus trees in river watershed and wetlands was cited as the cause of reduced water levels in rivers and streams. Farming on river banks is also a threat to the ecosystem resulting in sedimentation, siltation and change of course of some rivers. Exponential population increase is an issue which should be checked. Farmers mainly practise both crop subsistence and livestock farming to secure livelihoods. The ecosystem is vital to crop and livestock farming and social economic development. The area does not have piped water and residents depend on polluted river water for drinking resulting in waterborne diseases for instance cholera, dysentery and typhoid. The water in rivers is brown in colour because they pass through areas of settlement and cultivated fields and in the process they receive a lot of silts and sediments, and hence, the brown colour."

\section{Conclusion and Policy Recommendations}

\subsection{Conclusion}

Smallholder farmers need to choose, use, and capitalize on adaptation technologies to improve their livelihoods and wellbeing. Smallholder farmers need to choose, use, and capitalize on adaptation technologies to improve their livelihoods and well being, while enabling them to respond effectively to continuous and unpredictable climate change. To achieve food security and economic development, systems of food production and trade systems must be made more accessible for smallholder farmer. Funds from Green Climate Fund (GCF) as per the Paris Climate Change Conference 2015 must be made available for the smallholder farmers so that they can achieve their food production targets. Not all of this money will be invested in agriculture, but some will go into other sectors of investment to secure and improve livelihoods. Most of the financing will likely be offered as loans, not grants, to enable replenishment of the Fund. Adaptive strategies devised by incorporating the scientific and the indigenous experiences are very important in the designing of adaptive policies that will help residents in the region to adapt to the vagaries of climate change. Knowledge of the indigenous community which is based on observations, perceptions and experiences over the years can effectively be blended with scientific knowledge to improve climate change mitigation and adaptation strategies. Other strategies that should be considered when designing adaptive technologies include cost efficiency, co-benefits, trade-offs and feasibility. Sometimes vulnerabilities of a community may result from differences in traditions, culture, socio-economy, lifestyles and gender differentiated responses. The technologies to be adapted must be beneficial under the current climate conditions and those that might be adaptive under the future climate conditions. Technologies are supposed to build resilience to climate shocks and support adaptation. Without adequate scientific knowledge of future conditions, technologies can be ineffective or even harmful. Adaptation strategies should use both top-down and bottom-up approaches leading to higher effective, efficient, equal, sustainable, flexible, legitimate, robust and replicable. They need to be shaped in the context of available projected climate and impacts for the area under the study consideration. The way forward is to evaluate scenario methods and compare their strengths, weakness, and infrastructure and capacity requirements.

\subsection{Policy Recommendations}

\section{- A decent basic education to drive economic development}

Literacy level in the study area is wanting, worrying and low. A decent basic education is an important tool to drive economic development and improve livelihoods. To promote human resource development, education must be accorded top priority. The major reason for low education is the high levels of poverty. There is need to put up more institutions to expand education. The socio-economic 
development potential in the region can be unlocked through the enhancement of literacy levels. For instance, education will help eliminate glaring gender disparities at household levels and at the same time inspire behavior change by creating awareness of individuals and communities. A decent education will promote knowledge and skills to help apply technologies to protect the environment while working towards a brighter future. Education is an important tool to invest in because it can empower, spur and cushion families against livelihood challenges.

\section{- Accessing climate information is critical to adaptive decision making}

Accessing climate information and understanding impacts of climate change is critical to adaptive decision making in transforming livelihoods. In order for communities in the study area to effectively adapt to climate change, their wealth of indigenous knowledge must be complemented with scientific technical information that enables adaptive decision making. Through this research, there is need to create demand for information systems and help the community members to understand the value to use integrated traditional and scientific knowledge for planning. This applies to making decisions as when to plant crops and what quality of animals to be reared to improve the quality of livelihoods. It also involves short and long term decisions such as when to sell off the livestock and the economic trees and what to do with the family assets when climate threats are experienced.

\section{- Food security is becoming a complex problem in the area}

Due to high population density, most households own small parcels of land for crop subsistence farming (crops and livestock) in the research area. Food security is a major issue in the area and it is becoming a complex problem. Over nine out of every ten respondents (90\%) reported that they experience food shortage and had to eat less during certain months in the past year. Major food shortages occur between January and June. In addition, a sizeable proportion of the food consumed in households is bought when own production fall short of consumption needs. Unsuitable agricultural practices are still the norm in the study area and food security is dependent on maize, potatoes, beans, onions and tomatoes. To achieve food security locals should adopt Climate Smart Agriculture (CSA) to achieve improved livelihoods sustain economic development.

\section{- Poor management of animal diseases significantly contribute to low productivity}

Disease management remains a pressing challenge among livestock keepers in the study area due to ignorance, animal movement and open grazing systems. Animal diseases and pests contribute significantly to low productivity and lead to low income for livestock keepers. In addition, disease outbreaks impact livestock trade and the prevalent livelihoods. It is for these reasons that diseases be identified as a critical area for livestock management. Good management of livestock will enhance productivity and commercialize the livestock sector, ensuring livestock keepers earn handsomely for their efforts. New livestock management should be done through co-operatives which will provide access to credit at zero interest. This credit can be used to open and scale up agro vets from which farmers can buy drugs to treat their animals thereby help to enhance animal health service delivery for their members. This will enable livestock farmers access animal health services and lessen drug shortages and grow health services. This will enhance monthly income from livestock sales in order to improve livelihoods. A new programme should be put in place for the purposes of vaccination, examination, treatment and de-worming.

\section{- Diversification of livelihoods impacted by climate change}

Diversification of livelihoods impacted by climate change is a fundamental strategy in building resilience but it must be done in an informed and empowered way in order for it to be effective. There is currently limited knowledge about the ability of communities in the study region to adapt to future climate change. It is important to improve the understanding of how to enhance community's capacity to adapt to a changing climate in the context of other environmental stresses. The decision to diversify is always driven by recurrent climate shocks and stresses to existing livelihood strategies. Having many options for securing food and income provides a people with alternatives when one strategy fails. However, in the absence of the necessary information and support, the effectiveness of diversification as 
a strategy for building livelihood resilience may be limited. Engaging in new activities requires new skills and knowledge that may not exist in the community, requiring capacity development and technical assistance from external actors. New livelihood strategies may also involve new risks, and these must be understood in order that the right mixes of strategies in the household portfolio.

\section{- Embrace potential for changes in gender roles and relations}

Climate change is a driver to gender roles and relations. As the impacts of climate change become more apparent, households in the study area are increasingly required to shift from traditional livelihood strategies and practices, and at the same time embrace potential for changes in gender roles and relations. Within households and communities, men and women have different roles and levels of adaptive capacity. Among the different communities that live in the study area, adaptive capacity is not the same. Unlike in the past, women in the Saboat community are now actively engaged in crop production and marketing. Men contribute in tilling farms with the help of oxen's and looking after livestock both which are important livelihood strategies. Community social structures are also changing whereby people living in closer proximity now have access to education and other ecosystem services. However, generally this has created limitations on the women's voice, movement and participation in public and household decision making which in turn creates limitations to their adaptive capacity. Roles of men and women are therefore not the same. In the practical sense, this is manifested by constraints to their access to information, opportunities to earn income and power to make decisions that affect the livelihoods of members of their household. Women in communities in the study area may be limited to realize the full potential to adaptation efforts. It is imperative that vulnerability and adaptive capacity must uncover these differences and build an understanding of the specific roles, responsibilities and challenges faced by both men and women in securing their livelihoods and adapting to climate change. This will enable households to plan for adaptation that is equitable by allowing women and men to build their individual, household and community resilience.

\section{- Area residents are faced with water stress of water quality and quantity}

Availability of water in the area is no problem but only a few household access piped water due to poor planning and management. One of the biggest threats facing livelihoods is the availability of the clean drinking water resource at household levels. Already residents in the study area are faced with water stress on the basis of water quantity and water quality. In future water scarcity will stress food production, trigger several new diseases, worsen fuel shortages which are already strained and retard economic development. Due to increased temperatures, diseases like malaria which is the Africa's biggest killer may become more prevalent in the area. The threat of malaria and waterborne diseases looms in the area though the county and national governments have tried to reduce mortality rates since independence time. Unreliable rainfall in the future will play a big role in any crisis over water resources.. All residents must practice efficiency by managing energy resources effectively. All must switch from non-renewable to renewable energy sources. Carry out more research to bring forth new ideas on how to exploit potential energy resources. The residents must carry out reforestation and expand forested areas or embrace green economy. All households must be advised to plant economic trees to increase their income.

\section{- Traditional energy sources are a prerequisite to environmental degradation}

Energy is a prerequisite to socio-economic development and securing livelihoods. However, the use of energy in the study area is both directly and indirectly associated with long term adverse environmental impacts which have significantly contributed to forest degradation due to cutting forest for biomass products. Energy production and consumption are instrumental in the region as residents continue to rely on traditional energy sources such as fuel-wood, charcoal, dung and agricultural residues. Other households rely on kerosene especially those living in trading centres. Reliance on these traditional energy sources have adverse health implications for women and children because of smoke in poorly ventilated indoor conditions as well as the time burdens associated with the collecting fuel-wood and agricultural residues. Although these energy sources are primarily derived from forest and 
farmlands, their removal contributes towards deforestation and its associated negative impacts on soils and water resources. Losses of forest cover, rising population, existing land conflicts and fragmentation, inefficient utilization of land have combined to create negative impacts on the soil and water resources. The availability of domestically produced energy in the region is influenced by environmental and climatic factors. The loss of forest cover due to demand for fuel-wood and charcoal has led to reductions in the amount of water flowing through rivers especially during the dry seasons and greater siltation caused by floods during heavy rains. The adverse effects of climatic events on energy production in the area are projected to grow due to climate change. Climate change could alter forest growth patterns and further shrink the availability of fuel-wood for energy and significantly lower the amount of water in rivers and promote siltation.

\section{- Integrate traditional and scientific adaptive technologies to adapt to climate change vagaries}

Smallholder farmers need to choose, use, and capitalize on scientific adaptation technologies to improve their livelihoods and well being, while enabling them to respond effectively to continuous and unpredictable climate change. To achieve food security and economic development, systems of food production and trade systems must be made more accessible for smallholder farmers. Adaptive strategies devised by incorporating the scientific and the indigenous experiences are very important in the designing of adaptive policies that will help residents in the region to adapt to the vagaries of climate change. Knowledge of the indigenous community which is based on observations, perceptions and experiences over the years can effectively be blended with scientific knowledge to improve climate change mitigation and adaptation strategies. Other strategies that should be considered when designing adaptive technologies include cost efficiency, co-benefits, trade-offs and feasibility. The technologies to be adapted must be beneficial under the current climate conditions and those that might be adaptive under the future climate conditions. Technologies are supposed to build resilience to climate shocks and support adaptation. Without adequate scientific knowledge of future conditions, technologies can be ineffective or even harmful.. Adaptation strategies should use both top-down and bottom-up approaches leading to higher effective, efficient, equal, sustainable, flexible, legitimate, robust and replicable. They need to be shaped in the context of available projected climate and impacts for the area under the study consideration. The way forward is to evaluate scenario methods and compare their strengths, weakness, and infrastructure and capacity requirements.

- Adopt Climate Smart Agriculture (CSA) to achieve food security and improve livelihoods.

Due to high population density, most households own small parcels of land for crop subsistence farming (crops and livestock) in the research area. Food security is a major issue in the area is becoming a problem. Over nine out of every ten respondents $(90 \%)$ reported that they experience food shortage and had to eat less during certain months in the past year. Major food shortages occur between January and June. In addition, a sizeable proportion of the food consumed in households is bought when own production fall short of consumption needs.

The adoption of Climate Smart Agriculture (CSA) would be a sure solution to achieving food security and economic development in the study area under a changing climate. Technology Justice (TJ) can be used as a lens to evaluate whether CSA is a climate smart for smallholder farmer in the study area on the basis of the fact that the agro-ecological approaches are essential in achieving sustainable development in the context of climate change. Furthermore, farmers should feature CSA as a solution to resolving many livelihood challenges and make agriculture development a priority in achieving food security and higher incomes in the study area.

Under this approach, smallholder farmers will be required to use agro-ecological approaches which are essential in achieving sustainable development in the context of climate change. Despite efforts to maintain the natural resource base, unsuitable agricultural practices are still the norm in the study area and food security is dependent on maize, potatoes, beans, onions and tomatoes. Climate change increases the likelihood of extreme and unpredictable weather, and so crop diseases that are new are likely to occur. This is a likely threat to food security in the area. Uses of chemical fertilizers are

justified as climate smart because they can be used to increase yields and reduce deforestation by

Vol. 1, No. 4, pp. 251-269

D.: 10.53935/2641-533x.v1i4.94

financial support.

Article History:

Received: 6 August 2018

Revised: 3 October 2018

Accepted: 8 November 2018

Published: 28 December 2018

(C) 2018 by the authors; licensee Academic Publishing Group

| 266 
reducing the need for agricultural expansion. However, uses of organic fertilizers are more recommendable than uses of inorganic ones.

Diversification of the crops increases resilience of smaller farmers to extreme weather events and climate change. It is imperative that CSA agriculture be funded from the Green Climate Fund (GCF) for adaptation and mitigation to promote agro-ecological approaches that are accessible to smallholder farmer and increase adaptive capacity. Adaptation funding should be invested in education and community services that enable smallholders to access and use agrochemical information and use of technical knowledge. Thus, we strongly recommend the use of Climate Smart Agriculture (CSA) as a solution to achieving food security and economic development.

\section{- Vulnerability to climate change including extreme events at local scales is influenced by} factors including land fragmentation, increased poverty levels and literacy levels.

Increasing exposure to climate shocks and stressors is only one dimension of increasing vulnerability to climate change in Kapsokwony Division. Adaptive capacity is a dynamic concept affected by a range of social, environmental, economic and political variables many of which are beyond the control of the households. The main asset base of adaptation is influenced by population growth, unplanned development leading to land fragmentation, poverty levels and low literacy levels. Recurrent climate shocks and poorly designed response mechanisms have undermined the community's ability to innovate and engage in flexible decision making. Traditional systems of adaptive management of resources and livelihoods have been overcome by external actors view development and policies that value the smallholder farmer way of life. All these factors play role in inhibiting adaptive capacity and increased vulnerability which must go beyond exposure and sensitivity to climate impacts to explore different dimensions of adaptive capacity. There is need to identify new adaptive options that reinforce and build upon existing adaptive capacity.

Adaptation actions should include mainstreaming ecosystem services diversify economic activities as well as improving adaptive management and learning skills and land management to create increased social and ecological resilience to climate change. The research will help area residents to understand the use of nature based and ecosystem services to help people adapt to climate change, such as: flood management through construction of trenches, contour grass strips and tree planting; river bank rehabilitation through natural re- generation and planting of indigenous tree species; slope stabilization through soil and water conservation structures, and diversification of livelihoods through nature based enterprises such as fruit trees, agro-forestry and bee keeping.

One of the main messages to emerge from the past decade of synthesis and assessments is that while climate change is a global issue, it has a great deal in regional variability. There is an indisputable need to improve understanding of climate system effects at these smaller scales, because these are often the scales of decision making in society. Understanding impacts of climate change at local scales will also help to target finite resources for adaptation measures. We recommend effective and efficient use of natural resources.

- Actions that develop agri-business for agricultural outputs to sale surplus farm produce.

Most agricultural development plans always focus on supply side intervention, such as improved seed and fertilizers. Many people pay too little attention to the demand side, the place where the increased production will ultimately end or go. This is a critical question which the researchers cannot dare ignore because if the question is not attended to fully, the increase will probably fail to produce the expected economic gains and will make it hard to proceed on with the program. Once the subsistence requirements have been met by the local communities and the households, there are three sources of demand: a) export markets (international and regional); b) domestic urban markets; and c) food processing.

The county and national governments can help facilitate the export of high value crops to the diasporas through the combination of the technical assistance, economic and political measures (such helping growers to meet the EU requirements and to expand tariff free access for local products. The government can also establish a breadbasket in the region to supply more maize, beans, potatoes and tomatoes to the market. Funding the farmers can empower them to buy the correct seed and avail water 
where necessary to increase food production. I would like to propose the practice of organic farming since it is the best pet in the modern world.

Food processing is attractive to many government agencies because it is both a source of demand for agricultural products and a job creator. Downstream processing might not be a solution because the USA and EU tariff regimes prefer raw products over processed ones. However, African countries can counter this particular problem by cutting their export taxes on those goods. Meanwhile as more urban centers continue to mushroom, processing for domestic farm products will become more attractive. The challenge is to ensure that quality standards and infrastructure, roads and power must be put in place to marketing a possibility.

Reliable domestic sources of demand are particularly important in areas where poor transport connections or lack of comparative advantages constrain the ability to access the required market. Strict compliance mechanisms must be put in place. Improved seed, fertilizer and good weather can cause a surge in the production causing the farmers to be unable to sell the surplus. Little export infrastructure, high domestic transport costs and low purchase power can make it uneconomical to enable the crop be moved to other regions with food shortage.

\section{- Efficient and effective early warning system structures to be put in place}

An Early Warning System (EWS) is a comprehensive monitoring framework for early detection and response to environmental threats. The provision of timely and effective information, through identified institutions, that allows individuals exposed to a hazard to take action to avoid or reduce their risk and prepare for effective response (ISDR). It is more than just a prediction because it comprises a chain of four elements, starting from knowledge of the risks faced through to preparedness to act on early warnings. The use of available technology such as mobile phones and community radio is an effective means of disseminating climate information and seasonal forecasting among smallholder farmers communities in the study area. Efficient and effective early warning system endows the communities with wider range of information and enhances their ability to take decision during climate extremes. Disaster management officers can benefit much more than they do hitherto from local communication structures to facilitate preparedness and emergency assistance in case of occurrence of climate change vagaries. Failure in any one part can mean failure of the whole system. The components of an efficient and an effective early warning system include the following: a) Risk knowledge: prior knowledge of the risks faced by communities; b) Warning service: technical monitoring and prediction service for these risks; c) Dissemination: dissemination of understandable warnings to those at risk; and d) Response capability: Knowledge and preparedness to act by those threatened. Before a decision is made, risks arising from both the hazards and the vulnerabilities should well be known and the patterns and in the said factors should be readily available. At the same time, the correct parameters should be monitored so the correct decisions can be made. Timely warnings generated should be understood by the people and the warnings should contain relevant and useful information.

The ability of users to successfully extract relevant and accurate information from the climate information products is fundamental for the correct decision to be reached from the accurate information products. There is need for attitude change to establish ways of working of the communities and organizations/governments that serve them in collaboration and involvement of all stakeholders to build links between all actors. This local context can be improved by incorporating IK/local knowledge and modern technologies through participatory methodologies which should be used to involve communities in hazard mapping and vulnerability assessments. Their knowledge can be used in validating the derived maps or creating new accurate ones. Since this exercise happens at the beginning of projects, it can also be used as part of an effort of getting community buy-in to the early warning system. Their knowledge can be used in validating the derived maps or creating new accurate ones. Since this exercise happens at the beginning of projects, it can also be used as part of an effort of getting community buy-in to the early warning system by use of conventional and indigenous or local knowledge.

Incorporating government officers from different sectors, and other users we were able to deliver the message in practical, usable terms. Having identified the hazards prevalent within a region, and having also understood the needs of the community members, the warning service would concentrate in forecasting the potentialities of the hazards. The use of two sets of warning services namely: 


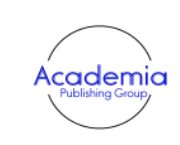

International Journal of Educational Studies Vol. 1, No. 4, pp. 251-269 2018

DOI: 10.53935/2641-533x.v1i4.94 Funding: This study received no specific financial support. financial support.

Article History:

Received: 6 August 2018
Revised: 3 October 2018

Accepted: 8 November 2018

Accepted: 8 November 2018

() 2018 by the authors; licensee Academic

Publishing Group
Conventional and indigenous/traditional/local methods. Conventional climate science identifies the hazards and the community vulnerabilities through the analysis of historical climatologically data patterns and trends of the hazards and vulnerabilities. The right parameters should be monitored based on a sound scientific basis for making forecasts in order to make accurate and timely warnings.

\section{Acknowledgement}

This paper has been prepared as parts of $\mathrm{PhD}$ research for the corresponding author investing the coping adaptive strategies and come up with new transformation knowledge that can help improve livelihoods and drive economic development in the study area. I am greatly indebted to them for their enormous contributions during the research period that has culminated into the fulfillment of this thesis. Thank you for the support, inspiration, motivation and encouragement throughout the challenging period of this accomplishment. I also wish to congratulate the entire elegant, meritorious team of lecturers and in particular Professor Shem Wandiga, the Director of the ICCA, University of Nairobi for their special contributions, inspiration, guidance and support that made it possible for me to achieve this realization. I do not want to forget my colleagues at ICCA Cohort 3 for their unrelenting and fantastic support, motivation and cooperation during course work. There are indeed very special people to me and to this accomplishment. I want to thank the Kenya Meteorological Department for providing the data for this study. I do not want to forget all those in one way or another played a role to realize this research findings. Lastly and not least, I would like to sincerely appreciate my mentors for taking through the journey of realising this particular dream.

\section{References}

Barrett, C. B. (2010). Measuring food insecurity. Science, 327(5967), 825-828.

Biagini, B., Laura, K., L., Gallager, K., \& Ortiz, C. (2014). Technology transfer for adaptation. Nature Climate Change, 4(9), 828-834.

Costello, A., Abbas, M., Allen, A., Ball, S., Bell, S., Bellamy, R., . . . Patterson, C. (2009). Managing the health effects of climate change. The Lancet, 373(9676), 1693-1733.

Cotty, P. J., \& Jamie-Garcia, R. (2007). Influences of climate on aflatoxin producing fungi and aflatoxin contamination. International Journal of Food Microbiology, 119(1-2), 109-115.

Inter Academy Council. (2004). Realizing the promise and potential of African Agriculture. Amsterdam Nagarajan: Inter Academy Council.

Nagarajan, S., Jagadish, S., K., H. S. V., Prasad, A. S., Thomar, A. K., Anand, A., . . K., A. P. (2010). Local climate affects growth, yield and grain quality of aromatic and non-aromatic rice in northwestern India. Agriculture. Ecosystems and Environment, 38(3-4), 274-281.

Nelson, K. C., Palmer, M. A., Pizzuto, J. E., Moglen, G. E., Angermeier, P. L., Hilderbrand, R. H., . . . Hayhoe, K. (2008). Forecasting the combined effects of urbanization and climate change on stream ecosystems: From impacts to management options. Journal of Ecology, 46(1), 154-163.

Schmidhuber, J., \& Tubiello, F. N. (2007). Global food security under climate change. Proceedings of the National Academy of Sciences, 104(50), 19703-19708.

Sherman, M. H., \& Ford, J. (2014). Stakeholder engagement in adaptation interventions: An evaluation of projects in developing nations. Climate Policy, 14(3), 417-441.

Sindani, B. B. (2013). Assessment of water quality of R. Kibisi in Mt. Elgon area using the Ephemeroptera, Plecoptera and Tricoptera richness index method.

Wesche, R. G. (1983). The high altitude environment of Mt. Elgon in Uganda and Kenya: Climate vegetation and the impact of fire. Eco-Tropical Monographs, 2, 1-253.

WWAP. (2009). The united nations world water development Report 3: Water in a changing world. Paris and London: UNESCO and Earth-Scan. 